\title{
The Effect of Total Asset Turnover and Profitability on Firm value with Good Corporate Governance as Moderating Variable in Food and Beverage Subsector Manufacturing Companies Listed on the IDX 2010-2019
}

\author{
Isnartik Bama1, Azhar Maksum, Abdhy Aulia Adnans ${ }^{1}$ \\ ${ }^{1}$ Department of Accounting, Faculty of Economics and Business at Universitas Sumatera Utara, Indonesia
}

Corresponding Author: Isnartik Bama

\begin{abstract}
The success rate of the company is often associated with stock prices. High stock prices will impact increasing the value of the company and increasing market confidence. This study aims to analyze the effect of total asset turnover and profitability on firm value in food and beverage companies listed on the Indonesia Stock Exchange for the 2010-2019 period. This study will also examine the good corporate governance variable used as a moderating variable in the research model.

The population is food and beverage companies listed on the Indonesia Stock Exchange for 2010 - 2019. From this population, 26 selected companies became the research sample, as many as 14 companies. Moreover, the numbers of observations used were 140 observations. The data type used is secondary data and the data analysis technique used in Panel Data Regression Analysis and Interaction Moderating Test with the help of EViews10 software.

The results of this study indicate that the alpha $5 \%$ profitability has a positive and significant influence on firm value. Meanwhile, total asset turnover has a positive but not significant effect on firm value. This study also indicates that good corporate governance can strengthen the influence of profitability on firm value. However, good corporate governance cannot moderate the effect of total asset turnover on firm value.
\end{abstract}

Keywords: total asset turnover, profitability, firm value and good corporate governance

\section{INTRODUCTION}

In the current digital 4.0 era, business competition is getting more challenging, so managers must develop strategies to compete with other companies and maintain their existence. The purpose of establishing the company, among others, is to maximize the profits earned by the company. Second, provide welfare for company members or shareholders. Moreover, the last is optimizing the company's value, which is reflected in the increase in its share price (Harjito \& Martono, 2005). The three goals of the company have a harmonious meaning, namely wanting to maintain the company's growth. Only the main emphasis that a company wants to achieve is different. The increase in the company's growth can be seen from the company's value, which is reflected in its share price so that the increase in the share price has a good impact on the image of the company's value. Meanwhile, the increase in stock prices is influenced by the company's performance in operating.

The company's value is an investor's perception of the company's level of success, which is often associated with stock prices. High stock prices will increase 
Isnartik Bama et.al. The Effect of total asset turnover and profitability on firm value with good corporate governance as moderating variable in food and beverage subsector manufacturing companies listed on the IDX 2010-2019.

the company's value and increase market confidence not only in the company's current performance but also in the company's prospects in the future. Stock prices and firm values summarize investors' collective assessments of how well a company is doing, both in current performance and prospects (Bearly, 2007). A company is said to have good value if the company's performance is also good. Entering a company into the capital market is an efficient option to attract investors to invest in the company. By showing the company has a high value in the eyes of investors, it can make investors believe in investing their funds in the company (Almahadin \& Oroud, 2019).

The goal of maximizing shareholder wealth can be achieved by maximizing the present value of all shareholder profits expected to be obtained in the future (Sartono, 2010). In this study, firm value is measured by using the ratio Price Book Value (PBV). PBV is a measure of the value that financial markets provide to the management and organization of a company as a company that continues to grow (Brigham \& Ehrhardt, 2005). This ratio shows how far a company can create firm value relative to the amount of capital invested. The higher the ratio, the more successful the company is in creating value for shareholders (Anis, 2004).

Tabel 1. Price To Book Value (PBV)

\begin{tabular}{|l|l|l|l|l|l|}
\hline \multirow{2}{*}{ No } & \multirow{2}{*}{ Stock Code } & \multicolumn{2}{|l|}{ PBV } \\
\cline { 3 - 6 } & $\mathbf{2 0 1 6}$ & $\mathbf{2 0 1 7}$ & $\mathbf{2 0 1 8}$ & $\mathbf{2 0 1 9}$ \\
\hline 1 & AISA & 1.58 & 0.35 & 0.16 & 0.16 \\
\hline 2 & ALTO & 0.01 & 1.86 & 2.29 & 2.18 \\
\hline 3 & CEKA & 0.90 & 0.85 & 0.41 & 14.78 \\
\hline 4 & DLTA & 4.37 & 3.48 & 3.75 & 4.07 \\
\hline 5 & ICBP & 5.61 & 5.11 & 5.56 & 5.73 \\
\hline 6 & INDF & 1.55 & 1.43 & 1.35 & 1.40 \\
\hline 7 & MLBI & 47.54 & 27.06 & 40.24 & 40.75 \\
\hline 8 & MYOR & 6.38 & 6.71 & 7.45 & 7.34 \\
\hline 9 & PSDN & 0.61 & 1.14 & 1.03 & 1.47 \\
\hline 10 & ROTI & 5.97 & 5.39 & 2.60 & 2.64 \\
\hline 11 & SKBM & 1.65 & 1.23 & 1.15 & 0.74 \\
\hline 12 & SKLT & 1.27 & 2.46 & 3.16 & 3.16 \\
\hline 13 & STTP & 3.82 & 4.26 & 3.08 & 3.03 \\
\hline 14 & ULTJ & 3.95 & 3.59 & 3.32 & 2.93 \\
\hline \multicolumn{5}{|l}{ Source $:$ IDX.co.id } \\
\end{tabular}

The rise and fall of the average price to book value (PBV) which reflects the value of companies in manufacturing companies in the food and beverage subsector in 2010-2019, is an interesting phenomenon to talk about, which can be seen in table 1. Price To Book Value (PBV) and 2. Profitability (ROA) below:

Table 2. Profitability (ROA)

\begin{tabular}{|c|c|c|c|c|c|}
\hline \multirow[b]{2}{*}{ No } & \multirow[b]{2}{*}{ Stock Code } & \multicolumn{4}{|l|}{ ROA } \\
\hline & & 2016 & 2017 & 2018 & 2019 \\
\hline 1 & AISA & 7.8 & -9.7 & -7.0 & 6.7 \\
\hline 2 & ALTO & -2.3 & -5.7 & -3.4 & 0.7 \\
\hline 3 & CEKA & 17.5 & 5.7 & 7.9 & 15.5 \\
\hline 4 & DLTA & 21.3 & 15.2 & 22.2 & 22.3 \\
\hline 5 & ICBP & 12.6 & 9.8 & 13.6 & 13.9 \\
\hline 6 & INDF & 6.4 & 4.9 & 5.1 & 6.1 \\
\hline 7 & MLBI & 43.2 & 37.1 & 42.5 & 41.7 \\
\hline 8 & MYOR & 10.8 & 6.9 & 10.0 & 10.6 \\
\hline 9 & PSDN & -5.6 & 4.7 & -6.7 & -3.4 \\
\hline 10 & ROTI & 9.6 & 3.1 & 3.1 & 4.4 \\
\hline 11 & SKBM & 2.3 & 0.2 & 0.9 & 0.1 \\
\hline 12 & SKLT & 3.6 & 2.7 & 4.3 & 0.1 \\
\hline 13 & STTP & 7.5 & 7.2 & 10.0 & 1.7 \\
\hline 14 & ULTJ & 16.7 & 13.3 & 12.6 & 15.7 \\
\hline
\end{tabular}

In Table 1, there is a fluctuation in the company's value, which is measured using Price to Book Value (PBV). Several factors can cause fluctuation in the value of the company. One of them is profitability. Profitability reflects the performance of a company where the higher the profit generated, the higher the value of the company, which has an impact on increasing investor confidence to invest in the company so that it becomes something that managers must pay attention to create activities that can increase company profits (Syaidah \& Saifi, 2017).

According to signalling theory, when profitability increases, it will have an impact on increasing firm value. However, this is not in line with Table 1. PT Multi Bintang Indonesia Tbk (MLBI) in 20162017 experienced a decrease in PBV value from 47.54-27.06. Meanwhile, the ROA value in the same year increased from 43.17 to 52.67. Likewise, PT Indofood Sukses Makmur Tbk (INDF) in 2015-2016 experienced an increase in PBV from 1.051.55. However, in Table 2 there was a decrease in the same year in the ROA value from 1.26-0.17. The difference in results between research data and existing accounting theory (Gap theory) is an 
Isnartik Bama et.al. The Effect of total asset turnover and profitability on firm value with good corporate governance as moderating variable in food and beverage subsector manufacturing companies listed on the IDX 2010-2019.

interesting phenomenon to research and reexamine.

Total asset turnover, or so-called total asset turnover, is part of the activity ratio. The higher the total asset turnover value shows the more significant the company's assets are in generating profits. It is an opportunity for investors to invest and trigger its stock price to rise (Kasmir, 2015). According to Syamsuddin (2011), total asset turnover is the efficiency level in using the company's overall assets to generate a specific sales volume. According to Brigham \& Houston (2010) is a ratio that measures the turnover of all company assets and is calculated by dividing sales by total assets. From this understanding, it can be said that total asset turnover is part of the activity ratio that measures the level of efficiency and effectiveness of all assets used by the company in increasing sales obtained from each rupiah of assets by comparing sales with total assets. This total asset turnover is essential for creditors, company owners, and company management to know so that the company's efficient use of all assets can be seen.

Profitability describes the company's ability to earn profits through all existing capabilities and sources. The ratio that describes the company's ability to generate profits is also called the operating ratio. According to Rudianto (2013), the profitability ratio measures the company's performance appraisal that shows the final result of a policy and decision. Profitability has a vital role in the company's survival, where when profitability is high, it reflects good company performance. So it indicates that the company has good Good Corporate Governance (GCG). Therefore, based on the relationship between profitability and GCG, in this study, GCG is determined as a moderating variable that moderates the relationship between total asset turnover and profitability with firm value.

At this time, the demand for the GCG paradigm in all economic activities is unavoidable. When GCG conditions can be achieved, it is hoped that a clean state will be realized and the formation of civil society and good corporate governance (Effendi, 2016). GCG is a principle that directs and controls the company to achieve a balance between the strength and authority of the company in providing accountability to interested parties such as shareholders in particular and stakeholders in general.

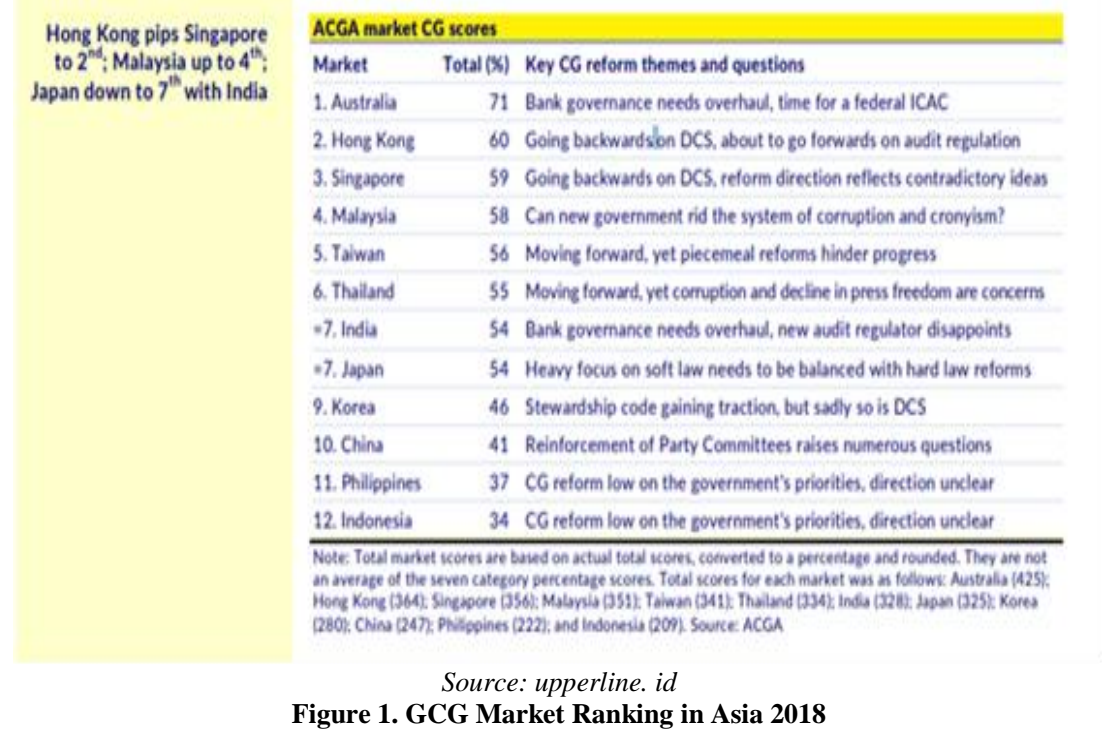

Based on the Corporate Governance Watch (CG Watch) research conducted by the ASEAN Corporate Governance Association (ACGA) in 2018, Indonesia ranks lowest in the implementation of Corporate Governance among 12 countries, namely Australia, Hong Kong, Singapore, Malaysia, Taiwan, Thailand, India, Japan, 
Isnartik Bama et.al. The Effect of total asset turnover and profitability on firm value with good corporate governance as moderating variable in food and beverage subsector manufacturing companies listed on the IDX 2010-2019.

Korea, China and the Philippines. CG Watch is research conducted every two years by ACGA based in Hong Kong, collaborating with Credit Lyonnaise Securities Asia (CLSA) on the quality of macro governance in 12 markets in the Asia-Pacific region (upperline. id).

Figure 1. above shows the ranking of increasing GCG implementation in Asia. Indonesia is in the lowest rank after China and the Philippines. The weak implementation of GCG is due to a lack of awareness of a value and primary practice in running a business, should the implementation of GCG increase the company's value.

This research was conducted on food and beverage sub-sector manufacturing companies listed on the Indonesia Stock Exchange in 2010-2019. Researchers are interested in researching this company because the food and beverage industry is still the mainstay of the manufacturing sector in Indonesia. The manufacturing industry is the highest sector that contributes to the economic sector. Most of them are non-oil and gas processing industries. Of these industries, food and beverage have the largest contribution portion, namely $6.33 \%$ of the national GDP in the first semester of 2018. (Kompas.com). It shows the importance of the role of the food and beverage industry on industrial growth and the national economy.

Based on the phenomenon of fluctuations in the PBV ratio in manufacturing companies in the food and beverage sub-sector in 2010-2019, gap theory and inconsistent research results (research gap), the researchers are interested in conducting a study entitled The Effect of Total Asset Turnover and Profitability on Firm Value. With Good Corporate Governance as Moderating Variable in Food and Beverage Sub-Sector Manufacturing Companies Listed on the Stock Exchange 2010-2019.

\section{Previous Research Review}

Several previous studies have researched this topic, and there are differences in research results. According to Alivia \& Chabachib (2013), the results show that the total asset mix significantly affects firm value. The results of this study are in line with Syamsuddin (2011), Aprilia et al. (2018), and Alivia \& Chabachib (2013). In contrast to Utami \& Prasetiono (2016) research, which states that total asset turnover has no significant effect on firm value.

Mufidah \& Purnamasari's research (2018) states that profitability has a significant effect on firm value. This is in line with research by Ulfa \& Asyik (2017), Pramana \& Mustanda (2016), Shalini (2020) and Nirmala \& Andarwati (2016). In contrast, Wulandari \& Widyawati (2019) research states that profitability does not affect firm value.

According to Bagaswara and Wati (2020), GCG strengthens the effect of the total asset turnover ratio on firm value. The results of this study are in line with Dewi \& Nugrahanti (2014) and Heder (2017). The research of Noviani et al., 2019 revealed that GCG is used to manage companies in increasing the company's profitability so that the better GCG in managing the company will increase the company's profitability. The results of this study are in line with Retno et al. (2012) and Latifah and Murniningsih (2017).

\section{Framework}

Following the description of the background of the problem, literature review and previous research, a conceptual research framework is prepared as follows:

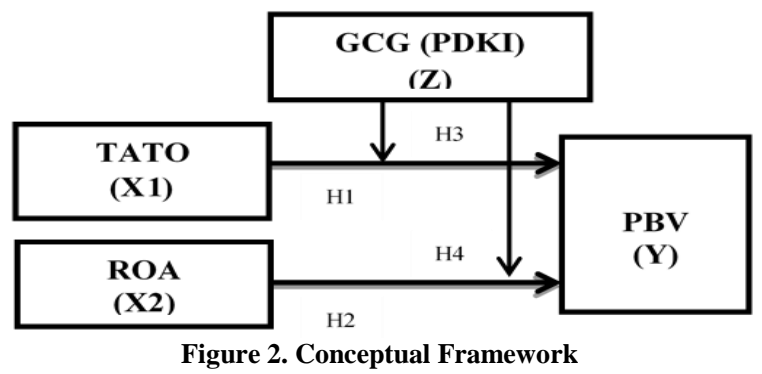


Isnartik Bama et.al. The Effect of total asset turnover and profitability on firm value with good corporate governance as moderating variable in food and beverage subsector manufacturing companies listed on the IDX 2010-2019.

H1: Total Asset Turnover has a positive and significant effect on Firm Value.

$\mathrm{H} 2$ : ROA has a positive and significant effect on Firm Value.

H3: Good Corporate Governance can moderate the effect of Total Asset Turnover on Firm Value.

H4: Good Corporate Governance can moderate the effect of Return On Assets (ROA) on Firm Value.

\section{RESEARCH METHODS}

This type of research is causal associative research to determine the effect of Total Asset Turnover and Profitability as an independent variable on firm value as the dependent variable with Good Corporate Governance (GCG) as the moderating variable. The causal associative study aims to analyze the relationship between one variable and another to know how one variable affects other variables (Sugiyono, 2014). The data analysis method used in this study is a statistical analysis method using the EViews application. Data analysis performs by testing standard assumptions and testing hypotheses.

The populations used in this study were 26 food and beverage sub-sector manufacturing companies listed on the IDX in 2010-2019. By using the purposive sampling technique, a sample of 14 companies was obtained multiplied by ten years of research to obtain 140 observations.

\section{RESULT AND DISCUSSION Normality Test}

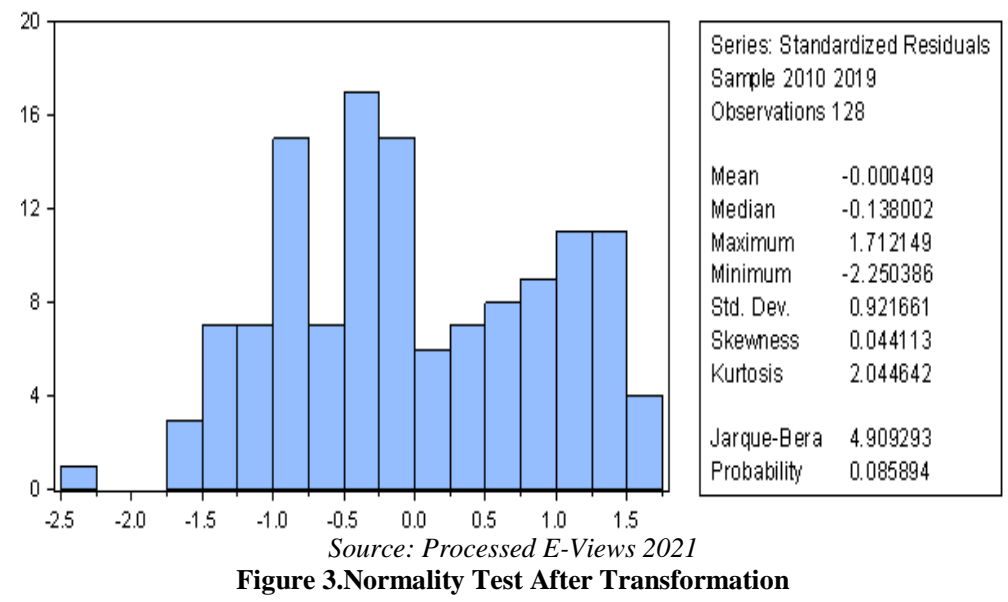

Based on the table above, it can be concluded that the probability value of 0.085894 is greater than 0.05 , so that the data is normally distributed. So that further testing can be carried out.
Panel Data Regression Estimation Model

To analyze panel data, the thing that must be done is to analyze the Common Effect Model (CEM), Fixed Effect Model (FEM) and Random Effect Model (REM) to determine the appropriate model to use.

\section{Common Effect Model Test}

Table 3. Common Effect Model Estimation Results

\begin{tabular}{|l|l|l|l|l|}
\hline Variable & Coefficient & Std. Error & t-Statistic & Prob. \\
\hline C & -0.146034 & 0.128236 & -1.138795 & 0.2568 \\
\hline LN X1 (TATO) & -0.046298 & 0.059072 & -0.783758 & 0.4345 \\
\hline LN X2 (ROA) & 0.940617 & 0.076927 & 12.22743 & 0.0000 \\
\hline \multicolumn{5}{|c}{ Source: Processed E-Views 2021}
\end{tabular}

From the regression results of common effect models, it is concluded that TATO has a negative effect on firm value. In contrast, ROA has a positive effect on firm value. 
Isnartik Bama et.al. The Effect of total asset turnover and profitability on firm value with good corporate governance as moderating variable in food and beverage subsector manufacturing companies listed on the IDX 2010-2019.

\section{Fixed Effect Model Test}

Table 4. Estimated Results of Fixed Effect Models
\begin{tabular}{|l|l|l|l|l|}
\hline Variable & Coefficient & Std. Error & t-Statistic & Prob. \\
\hline C & 0.111708 & 0.108199 & 1.032433 & 0.3039 \\
\hline LN X1 (TATO) & 0.008014 & 0.042812 & 0.187202 & 0.8518 \\
\hline LN X2 (ROA) & 0.557739 & 0.082076 & 6.795381 & 0.0000 \\
\hline
\end{tabular}
Source: Processed E-Views 2021

The regression results of fixed-effect models conclude that TATO and ROA positively affect firm value partially.

\section{Random Effect Model Test}

\begin{tabular}{l} 
Table 5. Estimated Results of Random Effect Models \\
\begin{tabular}{|l|l|l|l|l|}
\hline Variable & Coefficient & Std. Error & t-Statistic & Prob. \\
\hline C & -0.010666 & 0.186457 & -0.057202 & 0.9545 \\
\hline LN X1 (TATO) & 0.008148 & 0.087335 & 0.093295 & 0.9258 \\
\hline LN X2 (ROA) & 0.691558 & 0.108696 & 6.362323 & 0.0000 \\
\hline
\end{tabular} \\
\hline
\end{tabular}

The estimation results of random effect models conclude that TATO and ROA positively affect firm value partially.

\section{Panel Data Regression Selection Model}

There are three tests to decide which model to use: the Chow Test, Hausman Test, and Lagrange Multiplier Test.

\section{Chow Test}

\begin{tabular}{|l|l|l|l|} 
Table 6. Chow Test Result \\
\begin{tabular}{|l|l|l|l|}
\hline Effects Test & Statistic & d.f. & Prob. \\
\hline Cross-section F & 16.876689 & $(13,124)$ & 0.0000 \\
\hline
\end{tabular} \\
\hline
\end{tabular}

The table above shows that the probability value of 0.0000 is smaller than 0.05 , so the Fix Effect Model (FEM) is better than the Common Effect Model (CEM).

\section{Hausman Test}

Table 7. Hausman Test Result

\begin{tabular}{|l|l|l|l|}
\hline Test Summary & $\begin{array}{l}\text { Chi-Sq. } \\
\text { Statistic }\end{array}$ & $\begin{array}{l}\text { Chi-Sq. } \\
\text { d.f. }\end{array}$ & Prob. \\
\hline $\begin{array}{l}\text { Cross-section } \\
\text { random }\end{array}$ & 11.088273 & 2 & 0.0039 \\
\hline \multicolumn{4}{|c|}{ Source: Processed E-Views 2021 } \\
\hline
\end{tabular}

The table above shows that the probability value $=0.0039$ is smaller than 0.05 , so the model that is feasible to use is the Fixed Effect Model (FEM). The Lagrange Multiplier (LM) test aims to see between the CEM or REM models. This test is needed when the Chow test result is
CEM, and the Husman test result is REM. In this study, the results of the Chow test were FEM, so there was no need for the LM test.

\section{Hypothesis Test}

Table 8.Hypothesis Test Result

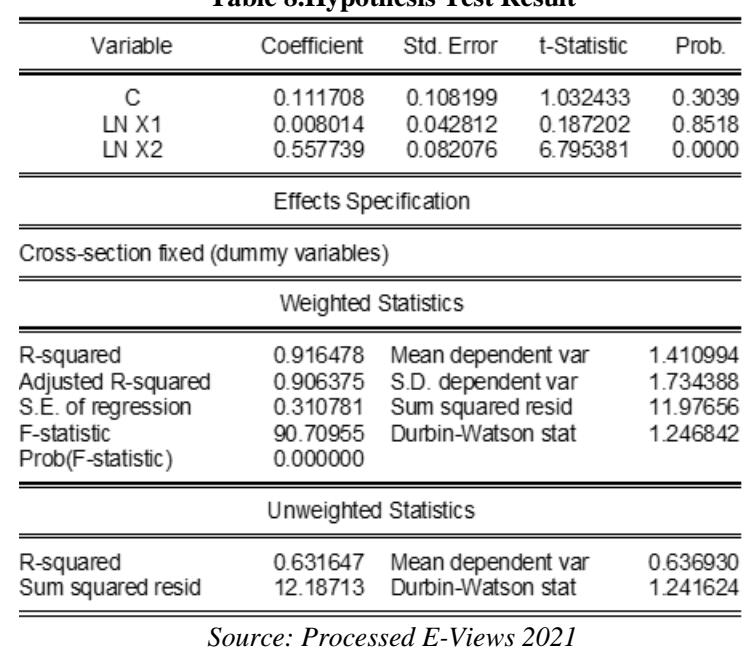

\section{Determinant Coefficient R2 (Goodness of Fit R2)}

Based on table 8 above, it can be seen that the value of Adjusted R Square is 0.906375 , which indicates that the role or contribution of the independent variable is total asset turnover and profitability, which can explain the dependent variable, namely the firm value of $90.63 \%$. In contrast, the remaining $9,37 \%$, is explained by other variables. 
Isnartik Bama et.al. The Effect of total asset turnover and profitability on firm value with good corporate governance as moderating variable in food and beverage subsector manufacturing companies listed on the IDX 2010-2019.

\section{Partial Test (t-Test)}

Based on the results of table 8 . with the transformation of the data obtained, the sig t-test is as follows:

1. Prob TATO with a value greater than $5 \%, 0.8518$, indicates that TATO has a positive and insignificant effect on PBV. Then $\mathrm{H1}$ is rejected.

2. Prob ROA, less than 5\%, which is 0.00000 , indicates that ROA has a positive and significant effects on PBV. Then $\mathbf{H} \mathbf{2}$ is accepted.

\section{Moderating Regression Analysis (MRA) Test}

Table 9. Moderating Regression Analysis Test Results

\begin{tabular}{crrrr}
\hline \hline Variable & Coefficient & Std. Error & t-Statistic & Prob. \\
\hline \hline C & 0.168799 & 0.124977 & 1.350634 & 0.1793 \\
X2 & -0.086668 & 0.167702 & -0.516798 & 0.6062 \\
X1Z & 0.469402 & 0.102157 & 4.594919 & 0.0000 \\
X2Z & 0.002203 & 0.155220 & 0.594012 & 0.5536 \\
& 0.673129 & 0.036161 & 2.022346 & 0.0453 \\
\hline \hline \multicolumn{5}{c}{ Effects Specification } \\
\hline \hline Cross-section fixed (dummy variables) \\
\hline \hline \multicolumn{5}{c}{ Weighted Statistics } \\
\hline \hline R-squared & 0.919105 & Mean dependent var & 1.264619 \\
Adjusted R-squared & 0.907833 & S.D. dependent var & 1.570002 \\
S.E. of regression & 0.299185 & Sum squared resid & 10.92043 \\
F-statistic & 81.53681 & Durbin-Watson stat & 1.233527 \\
Prob(F-statistic) & 0.000000 & & \\
\hline \hline & Unweighted Statistics \\
\hline \hline R-squared & 0.636921 & Mean dependent var & 0.636930 \\
Sum squared resid & 12.01266 & Durbin-Watson stat & 1.284547 \\
\hline \hline
\end{tabular}

From the results of Table 9, the MRA test above shows that the variable $\mathrm{z}$, Good Corporate Governance (GCG), does not moderate the relationship between the total asset turnover (TATO) and firm value. It can be seen from the probability results of 0.5536 , which is greater than 0,05 . Then the variable Good Corporate Governance (GCG) moderates the relationship between Profitability (ROA) and firm value. It can be seen from the probability value of 0.0453 , which is smaller than 0.05 .

\section{CONCLUSION}

Based on the results of data analysis and research discussion, the following conclusions can be drawn:
1. Total asset turnover proxied using Total Assets Turn Over (TATO) partially has a positive and insignificant effect on firm value as proxied using Price to Book Value (PBV).

2. Profitability proxied using Return On Assets partially has a positive and significant effect on firm value proxied using Price to Book Value (PBV).

3. Good Corporate Governance (GCG), which is proxied using the Proportion of the Independent Board of Commissioners (PDKI), does not moderate the relationship between the effect of total asset turnover proxied using Total Assets Turn Over (TATO) on firm value as proxied using Price to Book Value (PBV).

4. Good Corporate Governance (GCG) as proxied using the Proportion of the Independent Board of Commissioners (PDKI) moderates the positive relationship between Profitability as proxied using Return On Assets (ROA) and firm value as proxied using Price to Book Value PBV.

\section{LIMITATIONS OF THE RESEARCH}

1. The research sample is not wide enough because many food and beverage subsector companies have just been listed on the IDX in 2017 and 2019.

2. The lack of previous research on total asset turnover and good corporate governance as moderating variables.

\section{SUGGESTION}

1. For further researchers, it is better to examine all manufacturing companies in the consumer goods industry sector so that the sample is more extensive and relevant.

2. It is hoped that this research can be used as a reference for further research by adding other independent variables.

\section{Acknowledgement: None}

Conflict of Interest: None 
Isnartik Bama et.al. The Effect of total asset turnover and profitability on firm value with good corporate governance as moderating variable in food and beverage subsector manufacturing companies listed on the IDX 2010-2019.

\section{Source of Funding: None}

\section{REFERENCES}

1. Alivia,, N. R., \& Chabachib, M. (2013.). Analisis Faktor-faktor yang Mempengaruhi Nilai Perusahaan Dengan Profitabilitas Sebagai Variabel Intervening. Jurnal Of Management, 2(2).

2. Almahadin, H. A., \& Oroud, Y. (2019). Capital Structure-Firm Value Nexus: The Moderating Roleof Profitability. Revista Finanzas y Política Económica,, 11(2), 371382.

3. Anis, I. (2004). Analisis Price Book Value Ratio sebagai Keputusan Investasi: Penelitian pada Bursa Efek Jakart. Media Riset Akuntansi, Auditing dan Informasi, 4(1), 61-83.

4. Aprilia, R. (2018). Pengaruh Current Ratio, Total Asset Turnover, dan Debt to Equity Ratio Terhadap Price to Book Value dengan Return On Asset sebagai Variabel Intervening (Studi pada Perusahaan Sektor Industri Barang Konsumsi di Bursa Efek Indonesia Periode 2013-2017).

5. Bagaswara, A., \& Wati, L. N. (2020). Pengaruh Faktor Internal Dan Eksternal Terhadap Return Saham Dengan Moderasi Good Corporate Governance (Gcg). Jurnal Ekobis: Ekonomi Bisnis \& Manajemen, 10(2), 263-277.

6. Bearly, M. M. (2007). Dasar-Dasar Manjemen Keuangan Perusahaan (5 ed.). Jakarta: Erlangga.

7. Brigham, E. F., \& Ehrhardt, M. C. (2005). Financial Management: theory and practice (11th ed.). United States: South-Western.

8. Brigham, E. F., \& Houston, J. F. (2010). Dasar-Dasar Manajemen Keuangan (11 ed.). Jakarta: Salemba Empat.

9. Dewi, L. C., \& Nugrahanti, Y. W. (2014). Pengaruh Struktur Kepemilikan dan Dewan Komisaris Independen Terhadap Nilai Perusahaan (Studi Pada Perusahaan Industri Barang Konsumsi di BEI Tahun 20112013). Journal of Bussiness and Economic, 18(1), 64-80.

10. Effendi, M. A. (2016). The Power Of Corporate Governance: Teori dan Implementasi. Jakarta: Salemba Empat .

11. Harjito, A. D., \& Martono. (2005). Manajemen Keuangan. Yogyakarta.: Ekonisia.
12. Heder. (2017). Pengaruh Kinerja Keuangan Terhadap Nilai Perusahaan Dengan Good Corporate Governance Sebagai Variabel Pemoderasi. Jurnal Ilmu Dan Riset Akuntansi, 6(7), 309-321.

13. Kasmir. (2015). Analisis Laporan Keuangan (kesatu ed.). Jakarta: T. Raja Grafindo Persada.

14. Latifah, L., \& Murningsih , R. (2017). Pengaruh Kinerja Keuangan dan Good Corporate Governance Sebagai Variabel Moderasi terhadap Nilai Perusahaan ( Studi Empiris Pada Indeks Kompas 100 yang Terdaftar di Bursa Efek Indonesia Periode 2012-2016 ). THE 6th URECOL, 263-268.

15. Mufidah, N., \& Purnamasari, P. E. (2018). Pengaruh Profitabilitas Terhadap Nilai Perusahaan Dengan Pengungkapan Corporate Social Responsibility dan Good Corporate Governance Sebagai Variabel Moderating. Jurnal Keuangan dan Perbankan Syariah, 6(1).

16. Nirmala, A. M., \& Andarwati. (2016). Pengaruh Ukuran Perusahaan, Profitabilitas, PertumbuhanPenjualan dan Kepemilikan Manajerial terhadap StrukturModal dan Nilai Perusahaan Manufaktur di Indonesia(Perspektif Pecking Order Theory. Jurnal Aplikasi Manajemen (JAM), 14(3), 557-566.

17. Noviani, A. V., \& Atahau, A. D. (2019). Struktur modal, profitabilitas, dan nilai perusahaan: Efek moderasi. Jurnal Ekonomi dan Bisnis, 22(2), 391-415.

18. Pramana, I., \& Mustanda,, I. K. (2016). Pengaruh Profitabilitas Dan Size Terhadap Nilai Perusahaan Dengan Csr Sebagai Variabel Pemoderasi. EJurnal Manajemen Universitas Udayana, 5(1).

19. Retno, M., Dyah, R., \& Priantinah, D. (2012). Pengaruh Good Corporate Governance dan Pengungkapan Corporate Social Responsibility Terhadap Nilai Perusahaan (Studi Empiris Pada Perusahaan yang Terdaftar di Bursa Efek Indonesia Periode 2007-2010). Jurnal Nominal, 1(1).

20. Rudianto. (2013). Akuntansi Manajemen Informasi Untuk Pengambilan Keputusan Strategi. Jakarta: Penerbit Erlangga.

21. Sartono, A. (2010). Manajemen Keuangan Teori dan Aplikasi (4 ed.). Yogyakarta: BPFE.

22. Shalini, Witya. (2020). Pengaruh Struktur Kepemilikan dan Kinerja Keuangan Terhadap Nilai Perusahaan dengan 
Isnartik Bama et.al. The Effect of total asset turnover and profitability on firm value with good corporate governance as moderating variable in food and beverage subsector manufacturing companies listed on the IDX 2010-2019.

Kebijakan Dividen Sebagai Variabel Moderating pada Perusahaan Properti dan Real Estate yang Terdaftar di BEI Periode 2010-2018. Tesis. Universitas Sumatera Utara.

23. Sugiyono. (2014). Metode Penelitian Kuantitatif, Kualitatif dan R\&D. Bandung: Alfabeta.

24. Syaidah, U., \& Saifi, M. (2017). Pengaruh Intelllectual Capital Terhadap Nilai Perusahaan Dengan Profitabilitas Sebagai Variabel Moderasi. Jurnal Administrasi Bisnis, 64.

25. Syamsuddin, L. (2011). Manajemen Keuangan Perusahaan : Konsep Aplikasi dalam Perencanaan Pengawasan dan Pengambilan Keputusan. Jakarta:: Rajagrafindo Persada.

26. Ulfa, R., \& Asyik, N. F. (2017.). Pengaruh Kinerja Keuangan Terhadap Nilai Perusahaan Dengan Good Corporate
Governance Sebagai Variabel Moderasi. Jurnal Ilmu dan Riset Akuntansi, 7(10).

27. Utami, R. B., \& Prasetiono. (2016). Analisis Pengaruh TATO, WCTO, dan DER Terhadap Nilai Perusahaan dengan ROA Sebagai Variabel Intervening. Jurnal Of Management, 5(2).

28. Wulandari, A., \& Widyawati, D. (2019). Pengaruh Kinerja Keuangan Terhadap NilaiPerusahaan Dengan Good Corporate Governance Sebagai Variabel Mooderasi. Jurnal Ilmu dan Riset Akuntansi, 8(1).

How to cite this article: Bama I, Maksum A, Adnans AA. The Effect of total asset turnover and profitability on firm value with good corporate governance as moderating variable in food and beverage subsector manufacturing companies listed on the IDX 2010-2019. International Journal of Research and Review. 2021; 8(8): 559-567. DOI: https://doi.org/10. 52403/ijrr.20210875 